\title{
MANEJO DE Crotalaria juncea PARA FITORREMEDIAÇÃO DE SULFENTRAZONE E RISCO DE RECONTAMINAÇÃO DO SOLO
}

\author{
Ana Carolina Roos Pinheiro' \\ Raphaela Correia Pereira ${ }^{2}$ \\ Fabio Ribeiro Pires ${ }^{3}$
}

\begin{abstract}
Resumo: Alguns herbicidas apresentam atividade residual no solo, podendo interferir no desenvolvimento das culturas subsequentes. A fim de minimizar esse problema, têm-se empregado a fitorremediação. Diante disso, objetivou-se determinar a persistência do sulfentrazone no solo e a acumulação na parte aérea e raízes da espécie fitorremediadora Crotalaria juncea utilizando-se cromatografia líquida de alta eficiência. O delineamento experimental utilizado foi em blocos casualizados com parcelas subdivididas, em que o fator da parcela principal foram as doses do herbicida e o fator da subparcela as duas formas de manejo de C. juncea (ceifa e ceifa seguida de trituração), com quatro repetições. Não foi encontrado resíduo de sulfentrazone na parte aérea e raízes da espécie fitorremediadora, todavia detectou-se no solo. Não há risco de recontaminação do solo em se manter o material vegetal de Crotalaria juncea na área após fitorremediação de sulfentrazone.
\end{abstract}

Palavras-chaves: Adubo verde; herbicida; Descontaminação do solo; cromatografia.

\footnotetext{
1 Agronomia/UFES-Campus São Mateus, Brasil. E-mail: carol.pinheiru@gmail.com.

2 Agronomia/ UFES-Campus São Mateus, Brasil. E-mail: raphaela_correia@hotmail.com.

${ }^{3}$ Agronomia/ UFV- Campus São Mateus, Brasil. E-mail: pires.fr@gmail.com.
} 